\title{
The utilization of a Midwifery Obstetrical Unit (Mou) in a Metropolitan Area
}

\author{
M I Mashazi, M Cur Student, Department of Nursing Science, RAU \\ S D Roos, D Cur, Department of Nursing Science, RAU
}

\section{Abstract}

In this study an explorative, descriptive design which is contextual in nature, is utilized. The objective of the study is three-fold: Firstly, to describe the opinions of members of the community about the reasons for the under-utilization of the Midwifery Obstetrical Unit (MOU); secondly, to describe the suggestions of the community for improving the utilization of the MOU and thirdly, to describe intervention strategies for community nurses to improve the utilization of the MOU. Data was collected by means of focus group interviews, and was analysed using Tesch's (in Cresswell, 1994: 154-155) method of data analysis. Trustworthiness was ensured by using the method of Guba and Lincoln (1985).

The respondents were mothers who delivered their babies at the hospital, mothers who delivered their babies at the MOU, members of the Community Health Committee and MOU nurses.

Data was collected in two phases. Phase I dealt with the first question: What is your opinion about the reasons for the under-utilization of the MOU? Phase II dealt with the second question: What are your suggestions for improving the utilization of the MOU?

The four groups participated in Phase 1 as well as in Phase II, the reason being to involve the groups in identifying problems and finding solutions with which they would be comfortable, since it would be their ideas. This whole exercise was, however, carried out in line with the RDP principle of people driven approach or community involvement.

The investigation revealed that the community was not utilizing the MOU because of the following reasons:

- Negative attitudes of nurses.

- Lack of material and human resources.

- $\quad$ Poor safety and security measures.

- Lack of community involvement/participation.

The focus groups then identified the following suggestions for improving the utilization of the MOU:

- Change of attitudes by nurses towards the patients.

- Availability of material and human resources.

- Proper safety and security measures in the MOU.

- Community involvement/participation.

- Integration of health services.

Intervention strategies for community nurses to improve the utilization of the MOU were based on the literature as well as the suggestions made by the focus group respondents because the researcher found the suggestions to be realistic.

\section{Uittreksel}

In hierdie studie word ' $n$ verkennende, beskrywende ontwerp benut wat kontekstueel van aard is. Die doel van die studie is drieledig. Eerstens om die menings van lede van die gemeenskap met betrekking tot die redes vir die onderbenutting van die Vroedvrou Obstetriese Eenheid te beskryf, tweedens om die voorstelle van die gemeenskap ter verbetering van die benutting van die Eenheid te beskryf en derdens om intervensie strategieë te beskryf ten einde die benutting van die Eenheid te verbeter. Data is deur middel van fokusgroeponderhoude ingesamel en aan die hand van Tesch (in Cresswell, 1994: 154-155) se metode geanaliseer. Betroubaarheid was deur Guba en Lincoln (1985) se metode bewerkstellig.

Die respondente in die navorsing was moeders wie se babas in die hospitaal gebore is, moeders wie se babas in die Eenheid gebore is, lede van die Gemeenskapsgesondheidskomitee en verpleegkundiges werksaam in die Eenheid.

Data is in twee fases ingesamel. Fase 1 het gehandel oor die eerste vraag naamlik: "Wat is u mening aangaande die redes vir die onderbenutting van die Eenheid?" Fase 2 het die tweede vraag behandel naamlik "Wat is u voorstelle ter verbetering van die benutting van die Eenheid?" Die vier groepe het deelgeneem aan fase een en twee van die navorsing. Die rede hiervoor was dat, deur die groepe te betrek by die identifisering van probleme en die vind van oplossings, dit gemak sal bewerkstellig aangesien dit hulle idees sal verteenwoordig. Die operasie is dus uitgevoer aan die hand van die HOP beginsel van ' $n$ mensgedrewe benadering of gemeenskapsbetrokkenheid.

Die ondersoek het getoon dat die gemeenskap die Eenheid nie benut nie as gevolg van die volgende redes:

- Negatiewe houdings van verpleegkundiges

- Gebrek aan materiële en menslike hulpbronne.

- Swak veiligheidsmaatreëls.

- Gebrek aan gemeenskapsbetrokkenheid/deelname. 
Die fokusgroepe het die volgende voorstelle ter verbetering van die benutting van die Eenheid gedoen:

- Verandering in houding van verpleegkundiges jeens pasiënte.

- Beskikbaarheid van materiële en menslike hulpbronne.

- Behoorlike veiligheidsmaatreëls in die Eenheid.

- Gemeenskapsbetrokkenheid/deelname.

- Integrasie van gesondheidsdienste.

Intervensie strategieë vir gemeenskapsverpleegkundiges ter verbetering van die benutting van die Eenheid is baseer op die literatuur sowel as die voorstelle deur die fokusgroep respondente omdat die navorser die voorstelle as realisties bevind het.

\section{Introduction}

In the past, the community under study was deprived of maternity and obstetric services. The community was subjected to home deliveries and deliveries at hospitals which were situated at a distance of approximately $25 \mathrm{~km}$. This subjected the community to a high incidence of maternal and neonatal mortality in the Medical Officer of Health report (1996: 3-6).

The introduction of the National Health Policy brought about changes which necessitated the availability of midwifery and obstetrical units in the previously disadvantaged communities and the community under study was one of the beneficiaries of the proposals in the National Health Plan (1994:100). In fact, the midwifery obstetrical unit was built for this community and it was officially opened in August 1996.

Despite the availability of the services, members of the community still travel to the hospital for the delivery of their babies, which puts a further burden on the already overcrowded hospital while the MOU remains under-utilized. The underutilization of the MOU led to a threat of closure by the Regional Director, who cited the financial burden of running a unit which was not utilized by the community. The call for closure prompted the researcher to investigate the reasons why the unit is under-utilized by the community, and to try to find a solution to the problem.

The objectives of the study were as follows, namely to:

- explore and describe opinions of the community about the reasons for the under-utilization of the MOU;

- explore and describe the suggestions by the community for improving the utilization of the MOU;

- formulate intervention strategies to be utilized by community nurses to improve the utilization of the MOU.

\section{Terminology}

Terms used are defined as follows:

\section{Midwifery obstetrical unit}

This refers according to Myles (1991:1). to a unit that caters for the health needs of a pregnant woman during labour and post-delivery of her newborn baby. It is a specialised unit with appropriate equipment and trained staff

\section{Midwife}

Midwife refers to any person registered as a midwife with the South African Interim Nursing Council and who has been trained to assess and make decisions to save life (Myles, 1991:4).

\section{Community}

In this study community refers to the mothers who delivered their babies at the hospital, mothers who delivered their babies at the MOU, members of the Community health Committee who live in Eastern Gauteng Metropolitan Area, and MOU nurses working in the above-mentioned area.

\section{Community Health Committee}

This consists of elected voluntary community representatives (who are in the majority), representatives from health services in the area, non-government organizations working in the community, local health practitioners and others according to the National Health Plan for South Africa (1994:61).

\section{The Research Method}

An exploratory and descriptive research strategy was used to explore and describe the opinions of mothers who delivered their babies at the MOU, mothers who delivered their babies at the hospital, members of the Community Health Committee and MOU nurses about the under-utilization of MOU, and also to explore and describe the suggestions of mothers who delivered their babies at the MOU, mothers who delivered their babies at the hospital, Community Health Committee members and MOU nurses to improve the utilization of the MOU.

Data was gathered by means of interviews with four focus groups. The researcher, in her quest to find solutions to the problem acted as the facilitator and asked the respondents the following questions:

- What is your opinion about the reasons for the under-utilization of the MOU?

- What suggestions do you have to improve the utilization of the MOU?

A purposive sampling method was used to ensure full representation of the population which consisted of the following:

- Eight postnatal mothers who delivered their babies at the hospital (Group A) as well as six mothers who delivered their babies at the MOU (Group B), who are residents in the metropolitan area in Eastern Gauteng.

- Eight Committee Health members (Group C) of the specific community in the Eastern Gauteng Metropolitan area.

- Six MOU nurses (Group D).

One focus group interview was conducted separatly with each of the four abovementioned groups of respondents in order to address the first question namely "What is your opinion about the reasons for the under-utilization of the MOU? A second focus group interview was conducted with the same four groups of respondents in order.to answer the second question namely "What are your suggestions for improving the utilization of the MOU? Use was made of interpersonal skills by the researcher in order to stimulate the free expression of ideas 
by the four groups of respondents.

The method of data analysis as described by Tesch (in Cresswell, 1994:155). Data management included audio-taping of the eight different focus group interviews and transcribing it. The most descriptive words were found and it was then categorised into main and sub-categories. The data belonging to each category was assembled in one place for a preliminary analysis. When necessary the existing data was recoded. It was then sent to the independent coder for analysis. This external coder was selected from nurses with a Master's or Doctoral degree and who is knowledgable on interview data analysis. Concensus was reached regarding the categories and sub-categories which eminated from the data obtained.

Trustworthiness was addressed by means of Guba's model (in Lincoln \& Guba, 1985:289- 331). Credibility was ensured through prolonged engagement, triagulation and the authority of the researcher.

\section{Results of phase I of the study}

The results focus on:

\section{The opinions of the four groups of respondents about reasons for the under- utilization of the MOU}

The opinions of four groups of respondents, namely the mothers who delivered their babies at the hospital, the mothers who delivered their babies at the MOU, members of the Community Health Committee and MOU nurses, about reasons for the under-utilization of the MOU, will be discussed under four main categories, namely:

- Attitudes of MOU nurses towards the patients.

- Lack of material and human resources.

- $\quad$ Poor safety and security measures.

- Lack of community involvement/participation.

\section{Attitudes of MOU nurses towards the patients}

The MOU nurses were found to be rude, uncaring, unfriendly, cold and impatient by the mothers who delivered their babies at the MOU, mothers who delivered their babies at the hospital, as well as members of the Community Health Committee. This was confirmed by the MOU nurses, who acknowledged that they were rude and irritable and, notably that they are overworked because of the staff shortage in their unit (MOU). Amongst the MOU nurses, one nurse pointed out that being overworked does not give them any authority to be rude to their patients.

The responses from these four groups that negative attitudes of nurses make the MOU unpopular, hence it is not well utilized by the community, are confirmed by the literature.

According to Gillies (1989:397), nurses who are overworked become easily frustrated, emotionally drained and tend to treat patients as impersonal objects. Gillies further states that nurses who are overworked and who have inadequate knowledge and skills tend to have a low self-esteem and lack of confidence in what they are doing. This, in tum, will strain their relation- ships with patients and colleagues.

A similar study was conducted in Lebowa by Uyirworth, Itsweng, Mpa and Nkoane (1992:20), in which the researchers found that negative staff attitudes were the main reason given by mothers for not utilizing the maternity service. The mothers preferred to deliver at home, thus maintaining their dignity and privacy.

The White Paper on Health (1997:194) confirms that the majority of health workers have poor communication skills and fail to communicate effectively with their patients at district and community levels.

Poggenpoel (1997:30) further confirmed in her study that nurses communicated ineffectively with patients, they showed little concern, lack of empathy, intimacy and caring.

\section{Lack of material and human resources in the MOU}

Lack of material and human resources in the MOU was identified by the four groups of respondents (A, B, C and D), as one of the reasons why the MOU was under-utilized. They found the MOU to be lacking some of the facilities which are found in the hospital, such as public telephones, food for the patients, more nurses and doctors, transport and privacy, and this made them believe that the standard of care of the MOU is low compared to the hospital, hence the community rather visit the hospital and leave their MOU under-utilized.

This response is supported by Van Eeden (1989:140) who found that resources for health are inevitably limited and that consumers and providers are affected by this constraint. It does, however, subject the community to suffering as a result of inadequate infrastructure and the use of an alternative health facility which is inefficient.

Van Coeverden, De Groot, Davey \&. Howard (1992, 61:3536) reported that staff shortage in the Peninsula Maternity and Neonatal Unit created a problem for quality care by the midwives who were overworked and could not provide support and comfort for women in labour.

\section{Poor safety and security measures in the MOU}

Lack of safety and security in the MOU was raised by all fours groups (A, B, C and D) as risky and frightening, and they believed that their babies could be abducted, and their valuables could be stolen as the security officer of the MOU is undisciplined and does not carry a gun. The four groups felt that lack of safety and security in this MOU was one of the reasons for the under-utilization of the MOU by members of the community. This response is supported by literature which states that an increasing number of criminal activities occur in health centres, including the abducting of babies, car theft and burglary. Although the snatching of babies is an international problem, it is more pronounced in Gauteng Province and the following cases were reported:

The Star (13 July 1991) reported that baby Frederick Johannes Nagel was snatched from his mother's bedside at HF Verwoerd maternity ward. 
Baby Michaela Hunter, as reported in The Star, 4 May 1994, was snatched from a maternity unit (Marymount) by an unknown woman who posed as a nurse.

Criminal activities such as theft and burglary are committed on a daily basis throughout the country, and most of the cases are not reported, hence there is little literature on such activities in health centres. Locally, the following case was reported:

The Outlook, 15 June 1996 reported that a nurse's car was broken into and a radio-tape was stolen from the MOU.

\section{Lack of community involvement/ participation}

Members of the Community Health Committee (Group C) and the MOU identified lack of community involvement as one of the reasons for the under-utilization of the MOU. The Health Committee members felt that there was a lack of knowledge about the Reconstruction and Development Programme as well as communication between the community and MOU nurses, while the MOU nurses indicated that the community was not interested in health related matters, hence the concept of community involvement was not implemented and this created lack of interest with the result that the MOU is under-utilized by members of the community. The above response is supported by the literature, including the following:

According to Bang (1986:1395-1396) the health care in this country is characterised by a provider-driven approach and the community is at the receiving end. This creates apathy and dependency amongst communities.

The World Bank Publications further confirm that a lack of community involvement/ participation leads to a lack of accountability and no sense of ownership on the part of the community in Action for Better Health in Africa (1992:11).

The Nursing Journal RSA (1993:11) reports that health workers sometimes impose themselves on patients, voicing strong opinion which are not based on facts about the patients or mothers, forgetting that mothers are responsible adults who can take care of their babies.

Lack of community involvement and participation is supported by literature of the African National Congress' Reconstruction and Development Programme (1994:119). The lack of community involvement creates inefficiency in terms of service delivery and this is out of touch with the needs of ordinary people.

Heunis \& Van Rensburg (1996:3) further supports other sources, saying that lack of community involvement in healthrelated matters creates a lack of ownership and responsibility of the service within the community, which leads to neglect and possible vandalism.

\section{Results Of Phase II Of The Study}

The results focus on:

\section{The suggestions for improving the utilization of the MOU}

Suggestions by the four groups $[A, B, C, D]$ namely mothers who delivered their babies at the hospital, mothers who delivered their babies at the MOU, members of the Community
Health Committee and MOU nurses, will be discussed as five main categories, as follows:

- Change of attitudes by MOU nurses towards the patients.

- Availability of material and human resources.

- Proper safety and security measures.

- Community involvement/participation.

- Integration of health services.

\section{Changes of attitudes by MOU nurses towards patients}

Change of attitudes of MOU nurses towards the patients was suggested by mothers who delivered their babies at the hospital (Group A), mothers who delivered their babies at the MOU (Group B) and members of the Community Health Committee (Group C]) and that nurses need to change their attitudes to be more caring. MOU nurses (Group D) confirmed that they would change their attitude. They requested the authority to employ more nurses and to increase their salaries. The nurses also indicated that they would explain their situation to their patients with a view to regain the respect of their patients and this would improve utilization of the MOU by members of the community. The above responses are supported by a number of literature sources.

The question of attitude changes is further supported by a policy document for maternity services in the United Kingdom (1986) which indicates that midwives should have a supportive, caring and comforting attitude towards women in labour and lastly to prepare and strengthen them for the task of motherhood.

The World Health Organization (WHO) (1992:3) recommends that every woman has a fundamental right to proper neonatal care and that social emotional and psychological factors are decisive factors in the understanding and implementation of proper care.

Schroeder (1991:29) states that consumers are at the centre of the competitive market, that they expect quality care which encompasses interpersonal and technical care, and their description of quality care is in line with the professional scope of practice. These consumers will seek out health care settings that provide quality care and consumer satisfaction.

It is important to restructure the institution within the framework of consumer satisfaction so that the institution can be marketable and receive comments such as:

"Thank you for the fine care you gave my wife and the comfort given to me; I will definitely suggest to friends and family that your hospital is 'where to go'." (Schroeder, 1991:29$30)$.

Schroeder (1991:31) further stated that the health issues of the 1989s dealt with accountability for consumer services and that health issues of 1990 would deal with innovative, costeffective, interpersonal and highly technical care and ways to approach that accountability. Resources to facilitate delivery of these nursing services in an effective manner are essential today when cost containment, competition and nursing shortages are at the norm. 
According to Uyirworth et al. (1996:10), health workers should change their attitudes to be more caring and friendly and, as public servants, they must be accountable to the community which they serve.

The National Health Plan (1994:20) clearly states that health workers must respect the right to all people to be treated with respect and dignity. The Department of Health's White Paper on the Transformation of the Health System in South Africa (1997:103) also supports the response that health workers need to develop a caring ethos and to improve their attitudes towards patients and the community at large. The Health Department will work closely with training instructions and professional health organizations to address this issue effectively.

Nolte (1998:164) recommends that the midwife should adopt a supportive attitude towards a woman in labour. The midwife must create an environment conducive to personal growth, companionship and the promotion of social support. Since the woman's emotional needs evolve around labour, the presence, communication and care of the midwife can diminish anxiety and pain to a large extent.

\section{Availability of material and human resources}

The respondents from the four groups suggested that the authority must make available the necessary material and human resources to the MOU so that the latter will become efficient and effective like hospital maternity unit. This will attract the community to utilize their community-based MOU. Literature supports the above-mentioned response.

Maternity services should satisfy the emotional and physical needs of mothers by ensuring that sufficient staff is available and that resources are utilized efficiently and effectively in order to respond better to consumer pressure.

The WHO recommended thä the emphasis in finance should be on reallocating resources so that health care obtains a fair share of the budgeted resources and that supplies should be used to pay for health requirements, so that health providers can sustain their services economically.

Gerber (1987:29) reports that the success of an enterprise or service is based on two foundations, namely efficiency and effectiveness. The efficiency of an enterprise refers to the nature and quality of the interpersonal relationships within the enterprise. The effectiveness refers to "doing the right things", and is primarily determined by the availability of resources (human and material). Resources such as material and equipment are static and can only obtain a dynamic character through the intervention of labour resources (manpower). It is, however, true that the effectiveness and efficiency of human and material resources within an enterprise actually increase or boost the utilization thereof by the consumer.

Deficient primary care currently compels people to use hospitals for basic care, which causes overcrowding in hospitals, leaving primary health care centres or clinics under-utilized. There is consequently a need for an injection of additional resources to develop primary level infrastructure and services, so that the community will be attracted to utilize such services (African National Congress, 1994:76).
According to the MOU Policy Document (1995:2), the MOU should have the necessary resources in order to render effective services to the community.

\section{Proper safety and security measures}

The four groups of respondents (A, B, C and D) strongly emphasized the importance of proper safety and security in MOU to improve the morale of MOU nurses and patients, to diminish fear, enhance confidence and comfort and, in turn, to attract the community to utilize the MOU. Although not much literature is available on safety and security measures in health facilities, the MOU Policy Document (1995:3) gives some guidelines to support the response by the respondents that the MOU should have a security gate between the labour ward and the reception area, as well as an alarm system which is connected to the local Police Station.

\section{Integration of Local Authority and Provincial Health Services}

Integration of services was identified by the MOU nurses [Group D] as a suggestion to improve utilization of the MOU. This group believe that integration of services will improve staff shortages, co-ordination, communication and the relationship between local authority and provincial staff and, in turn, improve the services at the MOU, thereby automatically improving utilization of the MOU. Their response is supported in no uncertain terms by literature.

In the study conducted by Uyirworth $e$ al. (1996:11) it is recommended that child spacing and postnatal services be integrated in maternal and child health services to acquaint the black community with maternity services as complete and comprehensive services. The White Paper on Health (1997:98) also supports Uyirworth et al. (1996:11), stating that maternal and child health services should be comprehensive and integrated and should form an integral part of primary health care services. It should be rendered on a one-stop "supermarket" basis.

\section{Conclusions}

The MOU nurses demonstrated poor communication skills, lack of empathy and caring for their patients, and this has led to the development of dislike of the MOU by the community at large, hence the under-utilization of the MOU.

Lack of resources in MOU's reduces the general status of the MOU's significantly to the extent that maternity services rendered in these units (MOU's) are perceived to be of a lower standard compared to maternity services rendered at the hospitals hence the community is over-utilizing the hospitals and leaving the MOU's under-utilized.

Poor safety and security measures in MOU render the unit unsafe uncomfortable and unpopular for use by the community.

Lack of community participation in the MOU created lack of accountable sense of ownership amongst the community.

Change of attitudes by nurses towards their patients will make their services more attractive, acceptable and efficient to the 
community, and in turn, will improve the utilization of the MOU.

Availability of material and human resources in the MOU will ensure smooth running of the unit and will definitely attract the community from the hospital to the MOU.

The implementation of community involvement in this area will promote protection of the MOU nurses and patients by the community and there will be no need to demand that security officers carry guns to protect the MOU.

Integration of services will allow multi-purpose use of resources, such as personnel and it actually permits more outputs to be achieved.

\section{Recommendations}

The intervention strategies serve as recommendations as tabulated in table 1.

\section{Reference}

AFRICAN NATIONAL CONGRESS (ANC) 1994: Reconstruction and Development Programme. A policy framework (RDP). Johannesburg: Umanyano Publications.

AFRICAN NATIONAL CONGRESS (ANC) 1994: The National Health Plan for South Africa. Johannesburg:Umanyano.

BANG A 1986: Community participation FP Programme. Economic and Political Week, 9 August: 1935-1936.

CRESSWELL JW 1994: Research design: qualitative and quantitative approaches. Thousand Oaks California: Sage.

CURATIONIS ACCREDITED SOUTH AFRICAN NURSING JOURNAL OF THE DEMOCRATIC NURSING ORGANISATION OF SOUTH AFRICA (DENOSA), Volume 20 No. 3, September 1997.

GERBER PD 1987: Human resource management. Southern Book Publishers (Pty) Ltd.

GILLIES DA 1982: Nursing management: A systems approach. Philadelphia: WB Saunders Co.

GUBA EG \& LINCOLN YS 1984: Natural statistic inquiry. Londen, New Dehli: Sage Publications.

HEUNIS JC \& VAN RENSBURG HCJ 1996: Community involvement in primary health care: Guidelines for facilitation and evaluation. Centre for Health Systems Research and Development. University of the Orange Free State, Bloemfontein.

MILES M 1991: Textbook for midwives. Churchill:Livingston.

NOLTE AGW 1998: A textbook for midwives. Johannesburg. J.L. van Schaik.
POGGENPOEL M 1997: Nurses responses to Patients Communication, Curationis. September 1997: 26-32.

SCHROEDER P 1991: Issues and strategies for nursing care quality. Encyclopedia of Nursing Case Quality. Gaitherburg. Aspan Publishers.

THE DEPARTMENT OF HEALTH: MOU Policy Document 1994. Pretoria.

THE DEPARTMENT OF HEALTH: White Paper for the Transformation of the Health System of South Africa (1997) Pretoria. Government Gazette.

THE DEPARTMENT OF HEALTH AND WELFARE SERVICES: Springs Medical Officer of Health. Report 1996. Springs Town Council.

UYIRWORTH GP; ITSWENG MD; MPA S; NCHABELENG E \& NKOANE H 1992: Obstetrics service utilization by the community in Lebowa. Northern Transvaal.

VAN COEVERDEN DE GROOT HA; DAVEY DA \& HOWLAND RC 1982: Peninsula Maternity and Neonatal Services. S.A. Mediese Tydskrif, 9 Januarie 1982.

WORLD HEALTH ORGANISATION 1993: Rapid Evaluation Method Guidelines for Maternal and Child Health, Family Planning and other Health Services.

\section{NEWSPAPER PUBLICATIONS AND JOURNALS}

Citizen, 18 July 1994.

Health Care Journal UK, 1986.

Nursing Journal, RSA Volume 8, 1993:11.

The Outlook, 15 June 1996.

The Star, 13 July 1995. 


\begin{tabular}{|c|c|c|}
\hline SUGGESTION & AIM & STRATEGY \\
\hline $\begin{array}{l}\text { Change of attitudes of } \\
\text { nurses towards the pa- } \\
\text { tients so that they will be } \\
\text { caring, supportive, pa- } \\
\text { tient, kind and under- } \\
\text { standing. }\end{array}$ & $\begin{array}{l}\text { To create a patient-friendly environ- } \\
\text { ment. } \\
\text { To make the MOU services more ef- } \\
\text { fective to the community, in order to } \\
\text { enhance utilization. }\end{array}$ & $\begin{array}{l}\text { Arrange in-service training on interpersonal and } \\
\text { communication skills. } \\
\text { Health workers to be motivated to develop a car- } \\
\text { ing ethos and to improve their attitudes towards } \\
\text { the patients and the community at large. } \\
\text { Encourage health workers to upgrade their edu- } \\
\text { cational level in order to enhance asser-tiveness, } \\
\text { confidence and sympathy in caring for their pa- } \\
\text { tients. } \\
\text { Incentives in the form of promotion or merit award } \\
\text { for best nurse who shows good interpersonal rela- } \\
\text { tions with her patients and colleagues, as well as } \\
\text { the best nursing care to her patients. } \\
\text { There must be fair compensation and recognition } \\
\text { for a job well done. }\end{array}$ \\
\hline $\begin{array}{l}\text { Availability of human } \\
\text { and material resources. }\end{array}$ & $\begin{array}{l}\text { To address the inequitable access to } \\
\text { health care caused by lack of resources. }\end{array}$ & $\begin{array}{l}\text { Perform needs analysis pertaining to personnel } \\
\text { and equipment, and support services such as medi- } \\
\text { cation and emergency services. } \\
\text { Ensure that the support services, such as suffi- } \\
\text { cient stock and equipment, reflect acceptable pro- } \\
\text { portions. } \\
\text { Establish a co-ordinating committee (composed } \\
\text { of MOU and hospital managers) to address effec- } \\
\text { tive and equitable allocation of resources. } \\
\text { Ensure availability of transport on a daily basis to } \\
\text { fetch food and stock from the hospital. } \\
\text { Install public phones for patients and relatives. } \\
\text { Ensure that the MOU has a reliable phone with a } \\
\text { connecting line to the referral hospital. } \\
\text { The MOU must have access to a reliable ambu- } \\
\text { tron or an advanced midwife with a nursing ad- } \\
\text { lance service. } \\
\text { Install lockers for safekeeping of patients' and } \\
\text { staff's kit and valuables. } \\
\text { of the population to be served. } \\
\text { the hospital maternity unit, to avoid disparities. } \\
\text { ine the babies after delivery. } \\
\text { Ensure that the MOU gets the same equipment as }\end{array}$ \\
\hline
\end{tabular}




\begin{tabular}{|c|c|c|}
\hline SUGGESTION & AIM & STRATEGY \\
\hline & & $\begin{array}{l}\text { ministration qualification. } \\
\text { The staff should consist of advanced midwives, sen- } \\
\text { ior professional nurses, professional nurses, auxil- } \\
\text { iary nurses and general assistants. } \\
\text { Administrative clerks, drivers and security guards, } \\
\text { who should have a daily coverage of all catego- } \\
\text { ries. } \\
\text { Ensure daily staff coverage and make provision for } \\
\text { sick leave. }\end{array}$ \\
\hline $\begin{array}{l}\text { Proper safety and secu- } \\
\text { rity measures }\end{array}$ & $\begin{array}{l}\text { To create a safe and sound environment } \\
\text { for patients and staff. }\end{array}$ & $\begin{array}{l}\text { The Following must be installed: } \\
\text { - A security wall or fence and entrance gate. } \\
\text { - A security door for labour ward entrance. } \\
\text { - Security windows alarm system which is con- } \\
\text { nected to the local Police Station. } \\
\text { - Carports for nurses' cars. } \\
\text { - There must be an adequate number of security } \\
\text { officers on duty. } \\
\text { - Security officers must be trained in advanced } \\
\text { safety skills. }\end{array}$ \\
\hline $\begin{array}{l}\text { Community involve- } \\
\text { ment and participation. }\end{array}$ & $\begin{array}{l}\text { To implement a people-driven process } \\
\text { (RDP) } \\
\text { To create a sense of ownership. } \\
\text { To promote responsive and appropriate } \\
\text { services delivery. } \\
\text { To mobilise and promote accountabil- } \\
\text { ity. }\end{array}$ & $\begin{array}{l}\text { Establish a sound community health committee. } \\
\text { Have regular meetings with the Community Health } \\
\text { Committee or Health Forum. } \\
\text { Involve the community in planning and implement- } \\
\text { ing their health-related projects. } \\
\text { Together with the Health Committee, identify and } \\
\text { prioritise community health needs. } \\
\text { Ensure participating process. } \\
\text { Ensure that the community and individuals are } \\
\text { involved as respected partners in their health- re- } \\
\text { lated issues. } \\
\text { Ensure collaborative, integrated planning and de- } \\
\text { cision-making. } \\
\text { Encourage communities to take greater responsi- } \\
\text { bility for their own health. } \\
\text { The MOU staff should maintain good relations with } \\
\text { the community through regular interaction. } \\
\text { Educate and inform the community about the } \\
\text { health-related issues affecting their lives; in the } \\
\text { same process, traditional values and beliefs should } \\
\text { be respected. } \\
\text { Advertise the MOU. }\end{array}$ \\
\hline
\end{tabular}




\begin{tabular}{||l|l|l|}
\hline SUGGESTION & \multicolumn{1}{|c|}{ AIM } & \multicolumn{1}{c|}{ STRATEGY } \\
\hline Integration of services & $\begin{array}{l}\text { To create a one-stop service for mother } \\
\text { and child care services. }\end{array}$ & $\begin{array}{l}\text { Unify the fragmented health services at all levels } \\
\text { into a comprehensive system. } \\
\text { Integrate provincial and local authority health per- } \\
\text { sonnel. } \\
\text { Integrate the activities of provincial and local gov- } \\
\text { ernments in a way which maximises effectiveness } \\
\text { and efficiency. } \\
\text { Creates same conditions of employment, including } \\
\text { benefits of all available health resources. } \\
\text { Integrate family planning, postnatal care, labour, } \\
\text { cervical screening and child welfare services. } \\
\text { Reorganise health system based on Primary Health } \\
\text { Care Services with effective referral system. }\end{array}$ \\
\hline
\end{tabular}

